\title{
Lichen community from an endangered forest under different management practices in central Argentina
}

\author{
Edith R. Filippini, Juan M. Rodriguez \& Cecilia Estrabou (*)
}

\begin{abstract}
Filippini, E.R., Rodriguez, J.M. \& Estrabou, C. Lichen community from an endangered forest under different management practices in central Argentina. Lazaroa 35: 55-63 (2014).

We studied a lichen community from 300 ha of native Espinal forest under different types of management, classified into the following sectors: temporary grazing, adjacent crops, landscaped, and conserved. We observed 20 trees in each sector, identified lichen species and measured coverage in grids of $0.2 \times 0.2 \mathrm{~m}$. We compared alpha and beta diversity plus coverage by sector using the Kruskal-Wallis and Mann-Whitney U tests. We also applied a Multiple Response Permutation Procedure, a Non-metric Multidimensional Scaling multivariate analysis and the Indicator Species Analysis to test associations. We found 34 species of lichens. Physciaceae was the dominant family in the community. Total lichen coverage was highest in the temporary grazing sector and lowest in the conserved sector. No significant differences were found in alpha diversity among sectors; however, beta diversity was higher in the conserved sector. Multivariate analysis also showed that different management practices determine changes in community composition.
\end{abstract}

Keywords: grazing, native forest, Physciaceae, Espinal, composition.

Resumen: Filippini, E.R., Rodriguez, J.M. \& Estrabou, C. Comunidad liquénica de un bosque en peligro de extinción, con diferentes situaciones de manejo en el centro de Argentina. Lazaroa 35: 55-63 (2014).

Se ha estudiado la comunidad de líquenes de un bosque nativo de Espinal de 300 ha bajo diferentes tipos de manejo definidos en sectores: pastoreo temporal, cultivos adyacentes, ajardinado y conservado. Se seleccionaron 20 árboles en cada sector, identificamos todas las especies liquénicas y medimos su cobertura en grillas de 0.2 x $0.2 \mathrm{~m}$. Comparamos la diversidad alfa y beta y también la cobertura por sector, usando los test de Kruskal-Wallis y Mann-Whitney U. Además aplicamos un Procedimiento de Respuesta Múltiple por Permutación, un análisis multivariado de Escalamiento Multidimensional No métrico y un Análisis Indicador de Especies para probar asociaciones. Encontramos 34 especies de líquenes. Physciaceae fue la familia dominante en la comunidad. La cobertura total de especies fue alta en el sector con pastoreo temporal y menor en el sector conservado. No se encontraron diferencias significativas en la diversidad alfa entre sectores; sin embargo, la diversidad beta fue mayor en el conservado. Los análisis multivariados mostraron también que diferentes manejos determinan cambios en la composición de la comunidad.

Palabras clave: pastoreo, bosque nativo, Physciaceae, Espinal, composición.

\section{INTRODUCTION}

Espinal forest is an endemic ecosystem in Argentina that has been almost completely destroyed because of agricultural use (NOY-MEIR \& al., 2012). Until the beginning of the twentieth century the Espinal vegetation still covered large areas, but nowadays in the Province of Cordoba, it only remains the $0.1 \%$ of its original distribution (ZAK \& al., 2008).
The disappearance of ecosystems involves the loss of diversity, including lichens. These organisms have an important role in forest ecosystems. Together with fungi, bryophytes, algae and bacteria compose a cryptogamic cover responsible for the $7 \%$ of the net primary production of terrestrial vegetation. They are also credited for almost the $50 \%$ of the biological nitrogen fixation on Earth, which shows its influence in regional and global

\footnotetext{
* Centro de Ecología y Recursos Naturales Renovables. Instituto de Investigaciones Biológicas y Tecnológicas. Universidad Nacional de Córdoba. Consejo Nacional de Investigaciones Científicas y Tecnológicas. Av. Vélez Sarsfield 1611 - X5000JJC Córdoba, Argentina. E-mail: edithfilippini@gmail.com
} 
biogeochemical cycles (WolfGANG \& al., 2012). Moreover, they are food for other organisms and provide materials for nest building (RICHARDSON \& Young, 1977; Will-Wolf \& al., 2002).

Furthermore, studies have shown that lichens species and communities- are sensitive to air pollution (Fernández SAlEgui \& al., 2006), climate change and habitat fragmentation, so these factors are most influential in their regional distribution. While locally, moisture and light incidence are the environmental variables determining the establishment of certain species (PÉREZ-VARGAS \& al., 2009; ELLIS \& COPPINS, 2010; BLANQUER \& al., 2010).

In relation to forest ecosystems, productiveaimed-managements change their internal environmental conditions affecting directly lichen communities (KIVISTO \& KUUSINEN, 2002). For example, fragmentation as a result of clearing for agricultural use and/or removal of tree species for timber modifies conditions of micro habitat and forest continuity. Therefore, these practices affect the richness and composition of lichen communities (QUIROGA \& al., 2008).

Some evidences are the decreasing of diversity and species substitution for those less sensitive. In particular, the loss of cianolichens species and the development of nitrophilous species (WOLSELEY \& al., 2006). Additionally, there are studies showing the sensitivity of certain species to the application of herbicides used in agriculture (NEWMASTER \& BELL, 2002; CARRERA \& CARRERAS, 2011).

The Espinal biodiversity was barely studied as well as the potential threat of clearing these forests for agricultural use (LEWIS \& al., 2009; ZAK $\&$ al., 2008). Moreover, no descriptions of the lichen communities from this Phytogeographic unit -almost extincted- are available.

The main aim of this paper is to describe the corticolous lichen community present in remnant areas of the Espinal and to analyze whether the different management of a forest determine changes in the composition and structure of that community.

\section{MATERIALS AND METHODS}

\section{STUDY AREA}

The study area is located southeast of the Province of Cordoba (Argentina), between the latitudes $32^{\circ} 21^{\prime} 6^{\prime \prime}$ South and $63^{\circ} 262^{\prime \prime}$ West. It comprises 300 ha of native forest belonging to the

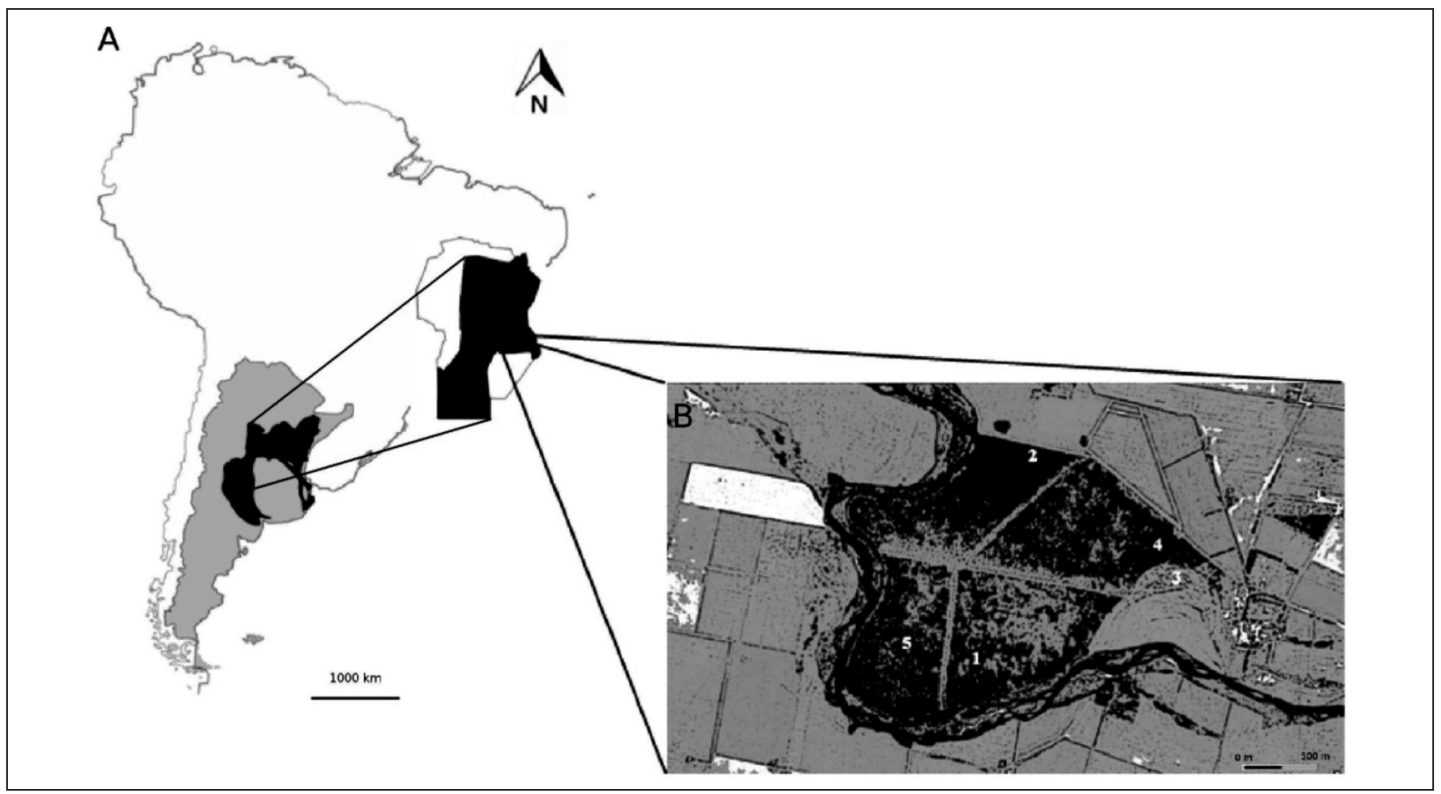

Figure 1. - Espinal area location in Argentina (in black) and in the Province of Cordoba (A)(modified from Lewis et $a l ., 2009)$. Location of transects in the four sampling sectors within the forest (B), 1, temporary grazing; 2 : adjacent crops; 3, landscaped and 4: maintained. 
phytogeographic province of the Espinal (LEWIS \& Collantes, 1973). The climate is temperate, with monsoon-water-regime type -dominated by summer rainfall- and xerophytic and deciduous vegetation type.

The study forest is surrounded in part by the Tercero River and is divided into four sectors by two pathways (Figure 1). These four sectors have been different management situations. Number 1 has a temporary use for grazing and is the furthest to the crops, whereas sector number 2 borders soybean crops and has no grazing. Sector number 3 was originally a forest continuity, but then it was selectively felled and it is now a park that preserves large specimens of Prosopis sp. and Celtis ehrenbergiana Gillet ex Planch. Today, the sector is daily used for grazing cattle guard. Finally, sector number 4 contains a fragment of a good-conservation-condition forest, with highrised tree specimens, dense shrub layer and it is excluded from livestock. It is worth to clarify that sector number 5 was not taken into account in this study since the profile of native forest is invaded by exotic species, -mainly Morus sp.

\section{Metodology}

Sampling was conducted between April and July 2012. Eight $100 \mathrm{~m}$ transects were laid, two in each sector. They followed east-west straight direction starting at $10 \mathrm{~m}$ from the roads to avoid the effect of the edge. They were separated from each other by $20 \mathrm{~m}$. In the sectors number 1 and 4 , transects passed through the forest interior. By contrast, in the sector number 2, transects were laid near crops and in the sector number 3 on isolated trees because of the physiognomy of the vegetation with higher light conditions in both cases specimens of Prosopis sp. and C. ehrenbergiana $(\mathrm{n}=80)$-with a diameter at breast height $(\mathrm{DBH})$ greater than $10 \mathrm{~cm}$ - were analyzed in each transect. A grid of $0.2 \times 0.2 \mathrm{~m}$ was placed at $1.5 \mathrm{~m}$ from the ground, on the southwest side of the trunk in each sampling unit or phorophyte (ESTRABOU, 1998; ESTRABOU \& al., 2005, 2011). Lichen species present within the grid were recorded and relative abundance was measured as the percentage of cover for each species on the grid. Relative frequency was also calculated as the number of phorophytes in which each species was present in relation to the total phorophytes studied.Species identification was carried out directly in the field, but when it was not achieved, samples were collected. Morphological characters were observed with optical microscope and histological cuts were prepared for making microscopic observations in the laboratory. Staining techniques were employed and thin-layer chromatography was additionally performed (CULBERSON \& al., 1981, ORANGE \& al.2001). A reference sample of each identified species is now deposited in CORD.

\section{STATISTICAL ANALYSIS}

Alpha diversity $(\alpha)$ was analyzed in each sector through the use of two indicators: $\mathrm{s}=$ richness by phorophyte (number of species by phorophyte) and Shannon diversity index $\left(\mathrm{H}^{\prime}=-\ln \right.$ $\Sigma$ pi $\times$ pi) (INFOSTAT, 2013). Furthermore, $\beta$ diversity was calculated with the formula of Whittaker (1972) $\beta=(\mathrm{Sc} / \mathrm{S})-1$, in which Sc is the number of species in a composite sample (combining a number of alpha samples), and $\mathrm{S}$ the mean number of species by phorophyte. This index is an optimal measure for analyzing the variation of communities in a set of transects in a non-environmental gradient. (ANDERSON \& al., 2011).

Both cover estimates and $\alpha$ diversity (Shannon) were compared with the Kruskal-Wallis non-parametric test and pairwise comparisons were made with the Mann-Whitney U -both with a significance level of $P<0,05$.

In addition, a multivariate analysis was performed using the PC-ORD. First, a multiple response permutation procedure (MRPP) was carried out to test the null hypothesis of no differences in the cover of the community due to different management of the forest. Secondly, a multivariate analysis of non-metric multidimensional scaling (NMS) type -fitted with a relativization by maximum values for each species- was applied on the matrix of percentage cover of species per site. Finally, an Indicator Species Analysis was performed, as a complement of the NMS, to test associations between lichen species and types of forest management (MCCUNE \& GRACE, 2002). 


\section{Table 1}

List of lichen species grouped by families; a: type of lichen growth; b: total cover throughout the sampling; c: average cover with its standard deviation (SD) and d: frequency (Freq.) calculated as number of phorophytes in which each species was present in relation to the total phorophytes studied. All values expressed in percentage.

\begin{tabular}{|c|c|c|c|c|}
\hline Species & $\begin{array}{l}\text { Type of } \\
\text { Growtha }\end{array}$ & $\begin{array}{c}\text { Total } \\
\text { Coverb }\end{array}$ & $\begin{array}{l}\text { Average Cover } \\
\quad(\mathrm{SD})^{\mathrm{c}}\end{array}$ & Freq \\
\hline \multicolumn{5}{|l|}{ Biatoriaceae $(<3 \%)$} \\
\hline $\begin{array}{l}\text { Bacidia campalea }(\text { Tuck.) S. Ekman \& Kalb } \\
\text { Candelariaceae }(<3 \%)\end{array}$ & Crustose & 36.2 & $0.45(1.47)$ & 0.14 \\
\hline $\begin{array}{l}\text { Candelaria concolor (Dicks.) Stein } \\
\text { Collemataceae }(8,82 \%)\end{array}$ & Foliose & 2.3 & $0.03(0.22)$ & 0.05 \\
\hline Collema sp. & Foliose & 64 & $0.8(1.96)$ & 0.23 \\
\hline Leptogium brebisonii Mont. & Foliose & 3 & $0.04(0.34)$ & 0.01 \\
\hline $\begin{array}{l}\text { Leptogium cyanescens (Ach.) Körb } \\
\text { Graphidaceae }(<3 \%)\end{array}$ & Foliose & 158.8 & $1.99(5.75)$ & 0.34 \\
\hline $\begin{array}{l}\text { Graphis scripta }(\mathrm{L} .) \text { Ach. } \\
\text { Lecanoraceae }(<3 \%)\end{array}$ & Crustose & 24 & $0.3(1.55)$ & 0.08 \\
\hline $\begin{array}{l}\text { Lecanora conizaeoides Nyl. ex Cromb. } \\
\text { Pertusariaceae }(<3 \%)\end{array}$ & Crustose & 12.1 & $0.15(0.59)$ & 0.11 \\
\hline $\begin{array}{l}\text { Pertusaria sp. } \\
\text { Physciaceae }(44,12 \%)\end{array}$ & Crustose & 0.5 & $0.01(0.06)$ & 0.01 \\
\hline Dirinaria applanata (Fée) D.D. Awasthi & Foliose & 9 & $0.11(0.6)$ & 0.04 \\
\hline Pyxine berteriana (Fée) Imshaug & Foliose & 6 & $0.07(0.57)$ & 0.03 \\
\hline Pyxine cocoes (Sw.) Nyl. & Foliose & 81 & $1.01(4.91)$ & 0.11 \\
\hline Pyxine subcinerea Stirt. & Foliose & 157.5 & $1.97(5.62)$ & 0.18 \\
\hline Heterodermia albicans (Pers.) Swinscow \& Krog & Foliose & 20.5 & $0.26(2.13)$ & 0.03 \\
\hline Heterodermia diademata (Taylor) Awasthi & Foliose & 59 & $0.74(3.19)$ & 0.08 \\
\hline Hyperphyscia adglutinata (Flörke) H. Mayrhofer \& Poelt & Foliose & 330 & $4.14(7.89)$ & 0.44 \\
\hline Hyperphyscia variabilis Scutari & Foliose & 47.5 & $0.59(3.52)$ & 0.05 \\
\hline Hyperphyscia tuckermanii (Lynge) Moberg & Foliose & 81.5 & $1.02(8.94)$ & 0.04 \\
\hline Physcia aipolia (Humb.) Fürnr & Foliose & 242 & $3.02(11.8)$ & 0.11 \\
\hline Physcia sciastra (Ach.) Du Rietz & Foliose & 8 & $0.1(0.89)$ & 0.01 \\
\hline Physcia endochryscea (Nyl.) Hampe & Foliose & 91 & $1.14(2.57)$ & 0.26 \\
\hline Physcia erumpens Moberg & Foliose & 21 & $0.26(1.4)$ & 0.04 \\
\hline Physcia rolfii Moberg & Foliose & 46 & $0.57(2.64)$ & 0.08 \\
\hline Physcia undulata Moberg & Foliose & 200 & $2.5(7.57)$ & 0.3 \\
\hline Parmeliaceae $(14,71 \%)$ & & & & \\
\hline Canoparmelia crozalsiana (de Lesd.) Elix \& Hale & Foliose & 180.5 & $2.26(10.73)$ & 0.16 \\
\hline Parmotrema pilosum (Stizenb.) Elix \& Hale & Foliose & 4.5 & $0.06(0.45)$ & 0.03 \\
\hline Parmotrema reticulatum (Taylor) Hale \& A. Fletcher & Foliose & 19 & $0.24(1.44)$ & 0.03 \\
\hline Punctelia hypoleucites (Nyl.) Krog & Foliose & 18 & $0.23(2.01)$ & 0.01 \\
\hline $\begin{array}{l}\text { Punctelia punctilla }(\text { Hale) Krog } \\
\text { Ramalinaceae }(<3 \%)\end{array}$ & Foliose & 12 & $0.15(0.87)$ & 0.04 \\
\hline $\begin{array}{l}\text { Ramalina celastri (Spreng.) Krog \& Swinscow } \\
\text { Stereocaulaceae }(5,88 \%)\end{array}$ & Fruticulose & 12.6 & $0.16(0.78)$ & 0.08 \\
\hline Lepraria $\mathrm{sp} 1$ & Crustose & 383.7 & $4.8(9.4)$ & 0.41 \\
\hline $\begin{array}{l}\text { Lepraria } \mathrm{sp} 2 \\
\text { Teloschistaceae }(5,88 \%)\end{array}$ & Crustose & 99.2 & $1.24(5.61)$ & 0.1 \\
\hline Caloplaca cerina (Vain.) Zahlbr. & Crustose & 27.5 & $0.34(1.16)$ & 0.15 \\
\hline $\begin{array}{l}\text { Xanthoria parietina }(\mathrm{L} .) \text { Beltr. } \\
\text { Verrucariaceae }(<3 \%)\end{array}$ & Foliose & 40.8 & $0.54(1.35)$ & 0.35 \\
\hline Placidium arboreum (Schwein. ex E. Michener) Lendemer & Squamulose & 49.5 & $0.62(2.29)$ & 0.16 \\
\hline
\end{tabular}




\section{RESULTS}

Thirty-four lichen taxa were found in the 80 phorophytes studied. 30 were identified to species level and only 4 to genus level. From the total of species, the type of lichen growth found were as follow: 26 foliose, seven crustose and one fruticose. Parmeliaceae and Physciaceae families grouped about the $60 \%$ of species: Physciaceae with 5 genera, where Physcia had the highest number of species -six. Parmeliaceae ranked on the second place in number of species, with three genera. The $40 \%$ of the remaining species (14) are distributed in nine families, with one or two genera each (Table 1).

In terms of cover, Lepraria sp1, Hyperphyscia adglutinata, Physcia aipolia, Physcia undulata, Canoparmelia crozalsiana, Leptogium cyanescens and Pyxine subcinerea had the highest overall percentages, in descending order. In contrast, those who had lower cover in increasing order were Pertusaria sp., Candelaria concolor, Leptogium brebisonii, Parmotrema pilosum, Pyxine berteriana and Dirinaria applanata. Similarly, Lepraria sp. 1, Heterodermia adglutinata, Xanthoria parietina and Leptogium cyanescens were the most frequent species whereas. Pertusaria sp., Physcia sciastra, Leptogium brevisonii and Punctelia hypoleucites appeared as rare with a very low frequency.

The lichen cover and diversity between the type of phorophyte were not different (richness $p=$ 0,492 and coverage $p=0,079$ ). Then the species of phorophyte was not included in the analysis.

When analyzing the lichen community per sector, significant differences emerged $(p=0.0035)$ in the percentage of total cover. The sector 1 sho- wed the highest cover and the sector 4 the lowest $(p=0.041)$, whereas sectors 2 and 3 were not significantly different. By contrast, no differences in the average of alpha diversity of the four sectors $(p=0.123)$ were found and the estimates calculated with the Shannon index $\left(\mathrm{H}^{\prime}\right)$ and the richness (S), resulted in similar values. Beta diversity indicated a high variability among the four sectors, but being sector number 4 the one with the highest value (Table 2).

The result of the MRPP showed highly significant differences in species composition of the four sectors of the forest. In pairwise comparisons, the statistic $\mathrm{T}$ had the most negative value when comparing sectors 3 vs. 4 . Hence, this was the strongest separation with the least probability for these differences are due to random (Table 3).

When observing the biplot of the NMS, it is noted that the shaft 1 separates most of the phorophytes from sector 4 to the right whereas phorophytes of sector 3 are mainly separated to the left. Phorophytes of sectors 1 and 2 are overlapped with the rest so they do not show a clear arrangement (Figure 2).

Meanwhile, species with more negative values in the shaft 1 as Physcia aipolia, P. hypoleucites, P. pilosum, P. endochryscea and Ramalina celastri are associated with phorophytes of sectors 2 and 3. Both clusters may help to the interpretation of shaft 1 meaning as a gradient of light.

The results of the indicator species analysis showed that 11 of the 34 lichen species were significantly correlated to the four sectors of the forest (Table 4).

Leptogium cyanescens and Physcia rolfii were indicators in the sector 4 (forest), whereas P. endochryscea, Lecanora sp. and Ramalina celastri

Table 2

Average cover with its standard deviation expressed in percentage, alpha diversity (richness, Shannon index and rank of species) and beta diversity $(\beta)$ in each sector. $\left(^{*}\right)$ indicate significant differences between sectors for average cover (Kruskal-Wallis $p<0.05$ ).

\begin{tabular}{llllll}
\hline Sectors & Average cover $(\mathrm{SD})$ & Richness $(\mathrm{SD})$ & Shannon $\left(\mathrm{H}^{\prime}\right)$ & Rank of species & Beta diversity $(\beta)$ \\
\hline 1 & $39.83(20.83)^{*}$ & $4.70(2.15)$ & 0.954 & $1-9$ & 6.23 \\
2 & $38.37(19.91)$ & $4.05(1.67)$ & 0.856 & $2-8$ & 7.4 \\
3 & $26.10(11.96)$ & $4.75(1.68)$ & 1.084 & $2-8$ & 6.16 \\
4 & $23.27(13.83)^{*}$ & $3.60(1.31)$ & 0.846 & $1-6$ & 8.44 \\
\hline
\end{tabular}


Table 3

MRPP for comparison between pairs of sectors (CBS; $\mathrm{T}=$ statistical measures the separation between groups. $P=$ probability of statistically significant differences with $p<0.05(*)$ and highly significant with $p<0.001(* *)$.

\begin{tabular}{ccc}
\hline CBS & $\mathrm{T}$ & $\mathrm{p}$ \\
\hline 1 vs. 2 & -2.7 & $0.014^{*}$ \\
1 vs. 3 & -7.77 & $0.000^{* *}$ \\
1 vs. 4 & -5.64 & $0.000^{* *}$ \\
2 vs. 3 & -2.69 & $0.013^{*}$ \\
2 vs. 4 & -7.38 & $0.000^{* *}$ \\
3 vs. 4 & -13.49 & $0.000^{* *}$ \\
\hline
\end{tabular}

had the same pattern in the sector 3 . In the sector 2, Heterodermia diademata and Physcia aipolia showed significant values as indicators. Graphis scripta, Collema sp., Lepraria sp. 2 and Pyxine subcinerea exhibited a similar behavior in sector 1 . These results are consistent with those obtained
Table 4

List of indications lichen species for four sectors: observed indicator value (OIV), expected indicator value (EIV), standard deviation (SD) and signification of Monte Carlo test $(P)$.

\begin{tabular}{lrllll}
\hline Species & Sector & OIV & EIV & SD & $p$ \\
\hline Leptogium cyanescens & 4 & 37.0 & 17.7 & 5.61 & 0.0072 \\
Physcia rolfii & 4 & 24.5 & 7.3 & 3.71 & 0.0022 \\
Physcia endochryscea & 3 & 44.3 & 13.8 & 4.24 & 0.0002 \\
Leptogium conizaeoides & 3 & 36.7 & 9 & 4 & 0.0002 \\
Ramalina celastri & 3 & 21.0 & 7.6 & 3.9 & 0.0082 \\
Heterodermia diademata & 2 & 16.6 & 7.3 & 3.67 & 0.0364 \\
Physcia aipolia & 2 & 26.7 & 9.1 & 4.04 & 0.0022 \\
Lepraria sp 2. & 1 & 29.1 & 8.8 & 4.19 & 0.0012 \\
Pyxine subcinerea & 1 & 20.1 & 11 & 4.15 & 0.0380 \\
Collema sp. & 1 & 21.1 & 12.1 & 4.1 & 0.0392 \\
Graphis scripta & 1 & 22.9 & 7.8 & 3.99 & 0.0080 \\
\hline
\end{tabular}

in the NMS analysis when grouping species and sectors. Therefore they are displayed in the biplot marked with crosses (Figure 2).

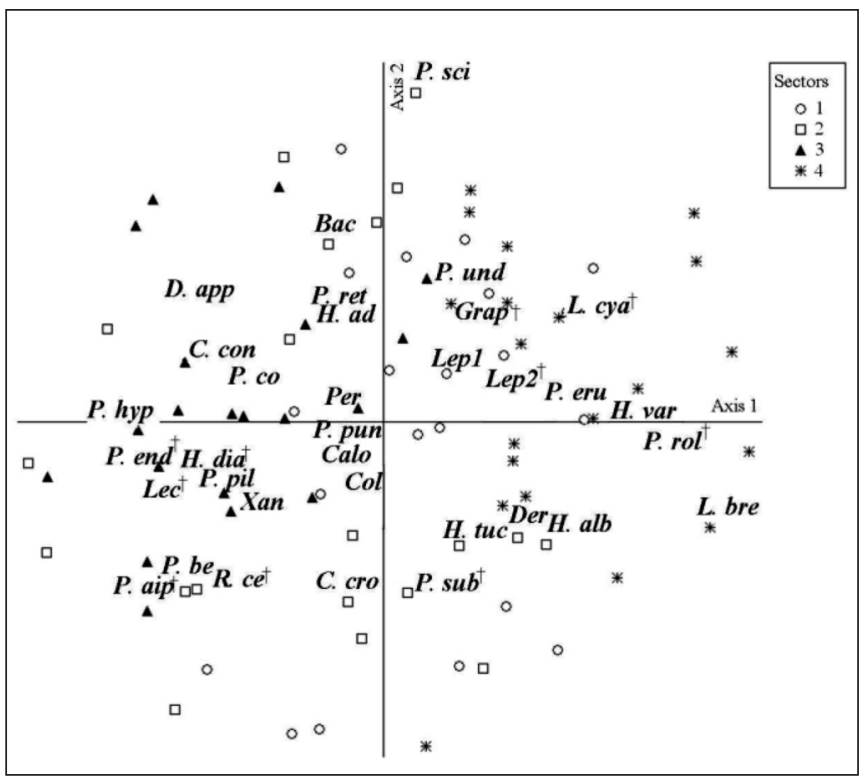

Figure 2. - Ordination (NMS) of 80 plots/sites in species space at four sectors with different management types. In the ordination, empty symbols ( 1 and 2 ) are plots from sectors with temporary grazing and adjacent crops, respectively. Full symbols (3 and 4) are plots from sectors landscaped and maintained. Candelaria concolor (C. con), Physcia rolfii (P. rol), P. undulata (P. und), P. endochryscea (P.end), P. aipolia (P. aip), P. erumpens (P. eru), P. sciastra (P. sci), Pyxine berteriana (P. be), P. cocoes (P. co), P. subcinerea (P. sub), Dirinaria applanata (D. app), Collema sp. (Col.), Leptogium cyanescens (L. cya), L. brebisonii (L. bre), Lecanora conizeoides (Lec), Ramalina celastri (R. ce), Heterodermia albicans (H. alb), H. diademata (H. dia), Lepraria sp. 2 (Lep2), Lepraria sp. 1 (Lep1), Graphis scripta (Grap), Caloplaca cerina (Calo), Endocarpon palidulum (Der), Hyperphyscia adglutinata (H. ad), H. tuckermanii (H. tuc), H. variabilis (H. var), Xanthoria parietina (Xan), Bacidia campalea (Bac), Pertusaria sp. (Per), Canoparmelia crozalsiana (C. cro), Parmotrema reticulatum (P. ret), P. pilosum (P. pil), Punctelia hypoleucites (P. hyp) and P. puntilla (P. pun). 


\section{DISCUSSION}

Primary our results contribute to the knowledge of a community described for the first time in the Espinal forests. Literature concerning to lichen communities in the Sierra Chaco Forest is available (ESTRABOU \& GARCIA, 1995; EsTRABOU \& al., 2005; QUIROGA \& al., 2008; RODRIGUEZ \& al., 2009), but there are few studies about plain forests (EstrabOU, 2007) and null ones for the Espinal.

Ecology studies of lichen communities in the Chaco region of central Argentina (EstRABOU, 2007) refer to a richness of macrolichens (21) what is similar to our results. However, in that former forest, the largest number of species belongs to the family Parmeliaceae (53\%) first and second to Physciaceae (24\%). That is opposite to the values we found, where Physciaceae family is dominant in the community (Table 1).

These differences in the composition of the community could be mainly explained by climatic differences between Chaco-forests, dry and warm and the Espinal, humid and less warm. It is important to take into account that regional climate is the most influential variable in controlling the composition of species (ELLIS \& CopPINS, 2010).

When comparing the studied community in relation to different management, it appears that cianolichen species were associated with the better preserved forest -sector 4 . The association of this group with the structural maturity of forests, is cited for numerous forest systems in the world -with high consensus-, regardless the types of climate and vegetation, (ARAGÓN \& al., 2010; RIVAS PlATA \& al., 2008; COPPINS \& COPPINS, 2002).

Although this type of habitat has neither high levels of alpha diversity nor high cover values, it plays an important role as a source of propagules for the recovery of lichen communities. It hosts sensitive species that could hardly tolerate drier conditions on a fragmented forest. Furthermore, the higher value of beta diversity indicates that this sector (4) has the highest variability among its phorophytes, with supports this idea.

The remnants of deforestation, such as the phorophytes in sector 3, are not a good habitat to sustain rich lichen communities. Probably, because of the extreme exposure and desiccation sensitive species could be diminished or even absent (Neitlich \& MCCune, 1997). Thus, only tolerant and sun-loving species such as Physcia endochryscea, Ramalina celastri, Parmotrema reticulatum and Dirinaria applanata would prosper in that environment. Total lichen coverage has not showed high values in sector 3 .

In relation to the forest in sector 1 , intermediate light conditions and no fragmentation favored to those phorophytes that provide the greatest cover of lichens to the system. This facilitated that a heterogeneous group such as Pyxine subcinerea, Punctelia punctilla and Collema sp. resulted indicators species.

Lichen community from the edge of the forest, adjacent to crops (sector 2), had values of total coverage and diversity that did not differ statistically from the rest. Heterodermia diademata and P. aipolia were indicators of the forest edge.

In conclusion the studied Espinal lichen community showed a particular species arrangement where Physciaceae was the most diverse family. Furthermore, different managements of this forest produce changes in coverage and species composition in the lichen community.

Considering that in the Province of Cordoba forested lands were reduced because of the advance of agricultural frontier (CABIDO \& ZAK, 1999) and lichen communities are contained in relictual forest, threatened by the habitat fragmentation and application of agrochemicals further studies are crucial. This work highlights the importance of conservation of forest ecosystems as a source for the maintenance and recovery of the diversity of lichen communities -and others associated with them. This could also be a useful tool in the development of management plans.

\section{ACKNOWLEDGMENTS}

The present study was supported by the Consejo Nacional de Investigaciones Científicas y Tecnológicas (CONICET) and the Ministerio de Ciencia y Tecnología de la Provincia de Córdoba, Argentina. 


\section{REFERENCES}

Aragón, G., Martínez, I., Izquierdo, P., Belinchón, R. \& Escudero, A. - 2010 - Effects of forest management on epiphytic lichen diversity in Mediterranean forests Appl. Veg. Sci. 13: 183-194.

Anderson, M.J., Crist, T.O., Chase, J.M., Vellend, M., Inouye, B.D., Freestone, A.L., Sanders, N.J., Cornell, H.V., Comita, L., Kendi, S., Davies, F., Harrison, S.P., Kraft, N.J., James, B., Stegen, C. \& Swenson, N.G. -2011 - Navigating the multiple meanings of $\mathrm{b}$ diversity: a roadmap for the practicing ecologist - Ecol. Letters 14: 19-28.

Blanquer, J.M., Sobrados, J.M., Villar, P. \& Pizarro, J. 2010 - Nueva colección de líquenes y hongos liquenícolas (Tierra de Fuego: Argentina-Chile) en el Herbario MAF - Lazaroa 31: 167-170.

Cabido, M.R. \& Zak, M.R. - 1999- Vegetación del norte de Córdoba - Secr. Agric. Gan. Rec. Ren. Prov. Córdoba. Ag. Córdoba Amb.

Carrera, M.F. \& Carreras, H.A. - 2011 - Efectos de la aplicación de glifosato sobre parámetros químico-fisiológicos en Usnea amblyoclada (Müll. Arg.) Zahlbr - Ecol. Austral 21: 353-361.

Coppins, A.M. \& Coppins, B.J. - 2002- Indices of ecological continuity for woodland epiphytic lichen habitats in the British Isles - Wimbledon, British Lichen Society. http://www.britishlichensociety.org.uk/ sites/ default/files/about-lichens-downloads/indices-ecological-continuity-woodland-epiphytic-lichens. pdf

Culberson, W., Culberson, C., Johnson, A. - 1988 - A standarized TLC analysis of $\beta$-orcinol depsidones - Bryologist 84: 16-29.

Ellis, C.J. \& Coppins, B .J. - 2010 - Partitioning the role of climate, pollution and old-growth woodland in the composition and richness of lichen epiphytes in Scotland Lichenologist 42: 601-614.

Estrabou, C. \& García, L. - 1995 - Comunidades liquénicas cortícolas sobre Lithraea ternifolia en las Sierras Chicas de la provincia de Córdoba, Argentina - Bot. Compl. 20: 35-43.

Estrabou, C. - 1998- Lichen species identification and distribution according tolerance to airborne contamination in the city of Córdoba, Argentina - In: Marcelli M.P. \& Seaward M.R.D. (Eds.). Lichenology in Latin America: History, Current Knowledge and Applications. Pp. 165-169. Cetesb, São Paulo.

Estrabou, C., Stiefkens, L., Hadid, M., Rodriguez, J.M. \& Perez, A. -2005 - Estudio comparativo de la comunidad liquénica de dos ambientes bajo estrés - Bol. Soc. Arg. Bot. 40: 3-12.

Estrabou, C. - 2007 - Preferencia de forófito por los líquenes en el bosque chaqueño oriental - Rev. Bosque 28 : 46-49.

Estrabou, C., Filippini, E., Soria, J.P., Schelotto, G. \& Rodriguez, J.M. - 2011 - Air quality monitoring system using lichens as bioindicators in Central Argentina Environ. Monit. Assess. 182: 375-83.
Estrabou, C., Quiroga, C. \& Rodríguez, J.M. -2014- Diversidad de la comunidad liquénica en un bosque remanente del sur del la región chaqueña - Rev. Bosque 35: 49-55.

Fernández Salegui, A.B., Arsenio Terrón, A. \& Barreno, E. -2006- Bioindicadores de la calidad del aire en La Robla (León, noroeste de España) diez años después Lazaroa 27: 29-41.

Kivisto, L. \& Kuusinen, M. - 2002- Edge effects on the epiphytic lichen flora of Picea abies on middle boreal Finland - Lichenologist 32: 387-398.

Lewis, J.P. \& Collantes, M.B. - 1973 - El Espinal Periestépico - Ci. Inv. 29: 360-377.

Lewis, J.P., Noentinger, S., Prado, D.E. \& Barberis, I.M. 2009- Woody vegetation structure and composition of the last relicts of Espinal vegetation in subtropical Argentina - Biodiv. Cons. 18: 3615-3628.

McCune, B.J. \& Grace, J.B. -2002 - Analysis of Ecological Communities - MjM Software, Gleneden Beach, Oregon.

Neitlich, P. \& McCune, B. - 1997- Hotspots of epiphytic lichen diversity in two young managed forests - Cons. Biol. 11: 172-182.

Newmaster, S.G. \& Bell, F.W. - 2002 - The effects of silvicultural disturbances on crytogam diversity in the boreal-mixedwood forest - Can. J. Forest Res. 32: 38-51.

Noy-Meir, I., Mascó M., Giorgis, M.A., Gurvich, D.E., Perazzolo, D. \& Ruiz, G. (2012) Estructura y diversidad de dos fragmentos del bosque de Espinal en Córdoba, un ecosistema amenazado. Bol. Soc. Arg. Bot. 47: 119133.

Orange, A., James, P.W. \& White, F.J. -2001 - Microchemical methods for the identification of lichens - British Lichen Soc.

Pérez-Vargas, I., Hernández-Padrón, C. \& Pérez de Paz, P. - 2009- Contribución al conocimiento de la Biota Liquénica Macaronésica - Lazaroa 30: 177-180

Quiroga, G., Estrabou, C. \& Rodriguez, J.M. -2008 - Lichen community response to different management situations in Cerro Colorado protected forest (Cordoba, Argentina) - Lazaroa 29: 131-138.

Richardson, D.H.S. \& Young, C.M. - 1977— Lichens and vertebrates. In: Seaward M.R.D. (Ed.). Lichen ecology. Pp. 121-144. Academic Press, London.

Rivas Plata, E., Lücking, R. \& Lumbsch, H.T. - 2008When family matters: an analysis of Thelotremataceae (lichenized Ascomycota: Ostropales) as bioindicators of ecological continuity in tropical forests - Biodiv. Cons. 17: 1319-1351.

Rodriguez, J.M., Estrabou, C., Fenoglio, R., Robbiati F., Salas M.C. \& Quiroga, G. - 2009- Recuperación post-fuego de la comunidad de líquenes epífitos en la provincia de Córdoba, Argentina - Acta Bot. Bras. 23: 854-859.

Will-Wolf, S., Esseen, P.A. \& Neitlich P. -2002- Monitoring biodiversity and ecosystem function: forests In: Nimis, P.L., Scheidegger, C. \& Wolseley, P.A. (Eds.). 
Monitoring with Lichens. Monitoring Lichens. Pp. 203222. Kluwer Academic Publ., Netherlands.

Whittaker, R.H. -1972- Evolution and measurement of species diversity - Taxon 21: 213-251.

Wolfgang, E., Weber, B., Burrows, S., Steinkamp, J., Büdel, B., Meinrat, O.A. \& Pöschl, U. -2012-Contribution of cryptogamic covers to the global cycles of carbon and nitrogen. Nat. Geosc. 5: 459-462.
Wolseley, P.A., Stofer, S., Mitchell, R., Truscott, A.N., Vanbergen, A., Chimonides, J. \& Scheidegger, C. 2006- Variation of lichen communities with landuse in Aberdeenshire, UK - Lichenologist 38: $307-$ 322.

Zak, M., Cabido, M., Caceres, D. \& Díaz, S. -2008What drives accelerated land cover change in central Argentina? - Environ. Manag. 42: 181-189.

Received: 16 June 2014

Accepted: 30 October 2014 